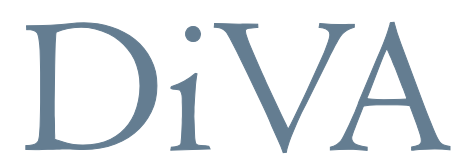

http://uu.diva-portal.org

This is an author produced version of a paper published in Renewable \& Sustainable Energy Reviews. This paper has been peer-reviewed but does not include the final publisher proof-corrections or journal pagination.

Citation for the published paper:

Grabbe, Mårten; Lalander, Emilia; Lundin, Staffan; Leijon, Mats

"A review of the tidal current energy resource in Norway"

Renewable \& Sustainable Energy Reviews, 2009, Vol. 13, Issue 8, pp. 1898-1909

URL: http://dx.doi.org/10.1016/j.rser.2009.01.026

Access to the published version may require subscription. 


\title{
A review of the tidal current energy resource in Norway
}

\author{
Mårten Grabbe \\ Emilia Lalander \\ Staffan Lundin \\ The Swedish Centre for Renewable Electric Energy Conversion \\ Division of Electricity, The Ångström Laboratory \\ Uppsala University \\ P.O. Box 534, SE-751 21 Uppsala, Sweden \\ Telephone: +46 (0)18 471 5843, Fax: +46 (0)18 4715810 \\ Email: Marten.Grabbe@angstrom.uu.se \\ Website: http://www.el.angstrom.uu.se/
}

Mats Leijon

\begin{abstract}
As interest in renewable energy sources is steadily on the rise, tidal current energy is receiving more and more attention from politicans, industrialists, and academics. In this article, the conditions for and potential of tidal currents as an energy resource in Norway are reviewed. There having been a relatively small amount of academic work published in this particular field, closely related topics such as the energy situation in Norway in general, the oceanography of the Norwegian coastline, and numerical models of tidal currents in Norwegian waters are also examined. Two published tidal energy resource assessments are reviewed and compared to a desktop study made specifically for this review based on available data in pilot books. The argument is made that tidal current energy ought to be an important option for Norway in terms of renewable energy.
\end{abstract}

Keywords: Tidal current, renewable energy, ocean energy

\section{Introduction}

Norway is well known for her offshore oil and gas industry. Today, as climate problems are at the summit of the international political agenda, perhaps it is time to also highlight the promising potential for renewable offshore energy resources in Norway, including offshore wind, wave, and tidal current energy. In this review article, the aim is to take a closer look at the tidal current energy resource in Norway.

We propose to review the somewhat limited published work-in terms of energy potential assessments, numerical modelling, experiments, and prototype construction-that has been done in this particular field against the background of the energy situation in general in Norway, the current state of tidal current energy research, the oceanographic characteristics of the Norwegian coastline, and scientific studies of tidal motion that have recently been undertaken with other purposes than energy extraction. Focus will be on the tidal energy resource itself, rather than on possible technical solutions to exploit this resource. Where applicable, international comparisons will be made. In the final discussion, we argue that tidal current energy ought to be a viable option for Norway as a renewable energy source, which deserves a considerably higher degree of attention from government, universities, and industry than what is currently the case.

\subsection{Energy supply in Norway}

In economical terms, Norway produces very much more energy than she consumes, due to her offshore oil and gas fields. According to official statistics [1], Norway in 2006 made domestic use of $14.9 \%$ of the total primary energy production for the year. The balance was exported, almost exclusively in the form of fossil fuels. The final domestic energy consumption (after losses etc. have been discounted) was $222 \mathrm{TWh}$, of which $48.6 \%$ was in the form of electricity.

The electricity production in Norway has traditionally been largely based on hydro power. In 2006, hydro power contributed $98.5 \%$ of the total electricity production in Norway, the mean annual production from hy-

Article published in Renewable and Sustainable Energy Reviews 13 (2009) pp. 1898-1909 
dro power being 120.9 TWh. Hydro power is still being developed, and the remaining exploitable resource is estimated to $39.4 \mathrm{TWh}$, excluding protected rivers [1]. Electricity produced in Norway is traded on the Nordic Power Exchange (Nord Pool ${ }^{1}$ ), a marketplace for electricity trading in Finland, Sweden, Denmark, and Norway. Norway also has grid connexions to Russia, and a 700 MW subsea cable (NorNed) to the Netherlands recently became operational ${ }^{2}$. The net electricity import in 2006 amounted to $0.7 \%$ of the total production in Norway [1].

Besides hydro power, renewable energy sources play a minor role in Norwegian energy supply. Of the 2006 final energy consumption, $6.6 \%$ came in other forms than fossil fuel or electricity, although it was not specified how much of this fraction came from renewable sources [1]. Wind power contributed $0.7 \mathrm{TWh}$ of electricity that year, just over half a per cent of the total electricity production.

As in many other countries, energy issues in general and renewable energy in particular are receiving a lot of political attention in Norway. The potential for wind and wave power in Norway has often been pointed out [2, 3]. There is no nuclear power programme in Norway, but the potential of thorium as an energy source was nevertheless recently investigated [4]. While not herself a member of the European Union, Norway is still influenced by the ambitious EU climate and energy goals, and in a recent report commissioned by the Ministry of Petroleum and Energy [5], it was suggested that Norway might become a major exporter of electricity—generated from hydro and offshore wind power-to the European market. Looking ahead, the Norwegian authorities have set a combined goal for renewable energy and energy efficiency of $30 \mathrm{TWh}$ increased annual production by 2016 over the 2001 level [6]. In light of this, it is likely that the interest in renewable energy sources will increase considerably in Norway in the coming years.

\subsection{Tidal currents as a renewable energy resource}

The increased attention on global warming and our dependence on fossil fuels have spurred interests in utilizing renewable resources to reach a sustainable power production. Ocean and tidal currents are obvious carriers of large amounts of energy, and over the years considerable effort has been spent both by academia and industry on finding better ways to produce electricity from this source.

One way to harvest the tidal energy is to build a tidal barrage in an estuary or a bay in high tide areas. The technology for tidal barrages is similar to that of run-ofriver hydro power plants. The well-known $240 \mathrm{MW}$ tidal barrage La Rance [7, 8, 9] was constructed during the 1960s in France and there are also a few smaller power stations in Canada, China, and Russia [10]. For some

\footnotetext{
${ }^{1}$ http://www.nordpool.com/

${ }^{2}$ http://www.statnett.no/
}

time, the possibility of constructing a tidal barrage in the Severn Estuary in the United Kingdom has been the subject of intense discussion $[11,12,13,14]$.

Tidal barrages have the benefit of using well-known technology, but on the other hand they require quite a bit of civil engineering work, the local environmental impact can be considerable, and the number of suitable sites is limited. Another way to harvest the tidal current energy is to extract the kinetic energy from the free flowing water, in a sense similar to wind energy conversion. Such energy converters have been called tidal in-stream energy conversion (TISEC) technology [15], marine current energy converters (MCEC) [16], or more commonly simply marine current turbines. By avoiding dams and large reservoirs, the detrimental impact on the local environment is thought to be kept to a minimum. Energy extraction with marine current turbines promises to be an environmentally friendly way to generate renewable electric energy with no emission of green house gases during normal operation. Technology development in this field is on-going, however, at present there are no full-scale marine current power farms in commercial operation.

Already at this early stage of development, it has been shown in a life cycle assessment (LCA) that the 1.2 MW Seagen marine current turbine [17, 18] compares well with for instance offshore wind turbines regarding carbon intensity and energy payback period [19]. Although it is not completely straightforward to compare results from different LCAs (due to e.g. the chosen system boundary and assumptions included in the analysis), the results from [19] are clearly promising for energy conversion from marine and tidal currents.

Other environmental effects-such as impact on the benthic ecology, noise, and possible environmental impact from deployment and decommissioning - are also discussed in the literature $[20,21,22]$. The impact is in many cases presumed to be small, however, more research and data from full-scale offshore experiments are needed before any definite conclusions can be drawn. It is likely that the environmental impact is dependent on site specific conditions as well as on the chosen technology.

Renewable energy sources can be both unreliable and intermittent, creating problems in power delivery and affecting the economic viability of projects. Tidal currents are intermittent, but also highly predictable in their nature. Furthermore, with a suitably chosen limited rated power of each device, tidal currents offer a relatively high capacity factor (or degree of utilisation) [23], which is vital for the economic viability of any renewable energy project [24]. Recent publications have suggested that the potential problems of intermittency and cost of backup generation (or redundancy) could be mitigated by developing sites that are phase shifted relative to each other. The aggregate output from the marine current turbines could then provide a base load. Such a 


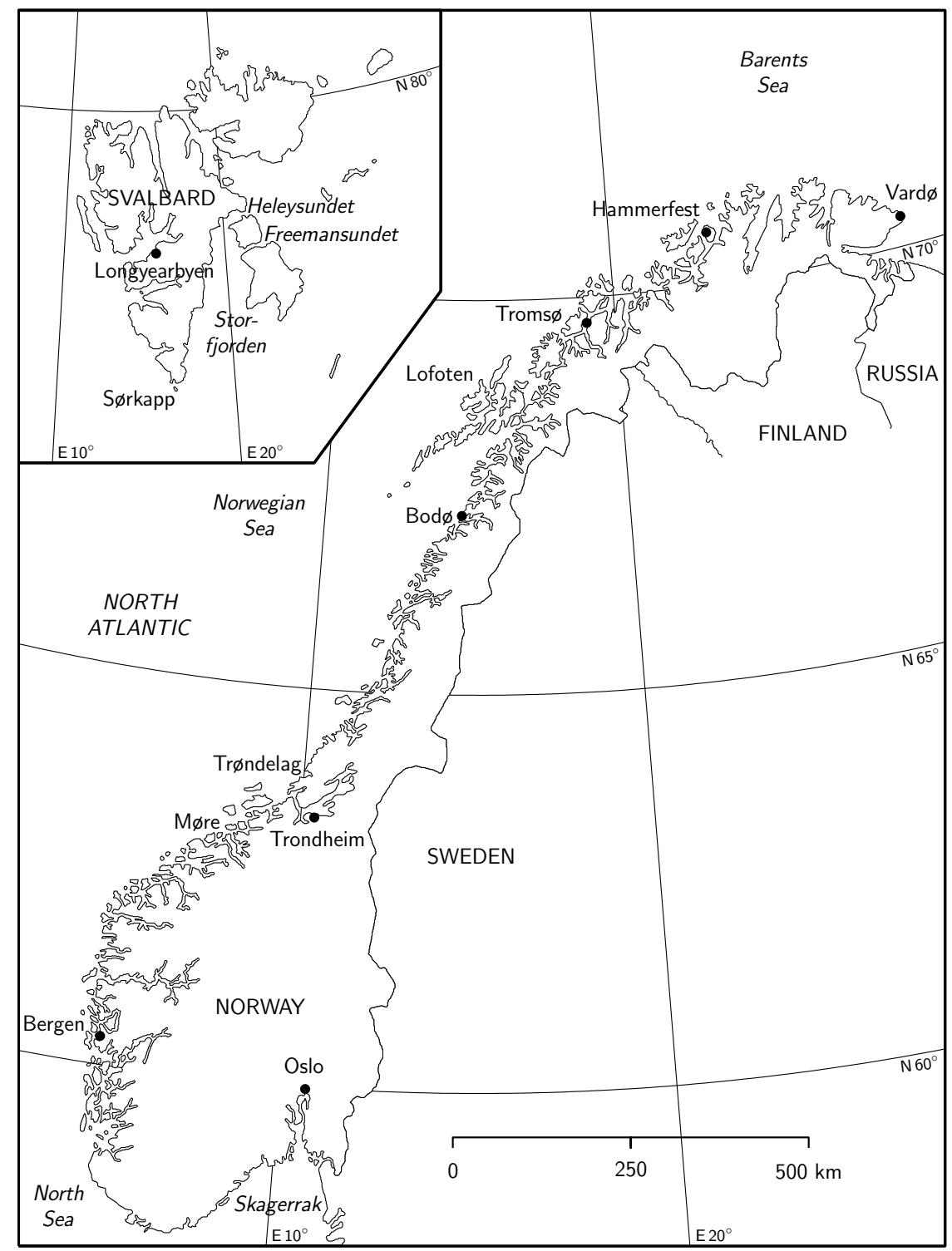

Figure 1: A map of the Norwegian coastline including Svalbard (inset). For a larger-scale map of the Lofoten area, see Fig. 2.

system would require a coastline where the tidal phase varies with geographical location, as is for instance the case in the British Isles [23, 25].

Researchers around the world have put a lot of effort into developing the theory on how to correctly assess the tidal current energy resource. These reports focus on how much energy that can be extracted from a site with a certain characteristic geometry, for instance in a simple uniform channel [26, 27], a channel with varying cross section linking two large bodies of water [28], a channel connecting a bay to a large basin [29, 30, 31], or sites where the flow is less restricted such as the accelerated flow around headlands [32, 33]. It is clear from this work that the extractable potential is site dependent and not always simply proportional to the kinetic energy in the undisturbed tidal current.

For a tidal channel with a large cross-sectional area compared to that of the turbine, the situation could be said to be analogous to the results derived by Betz for power extraction in an unconstrained flow, where the maximum available power is roughly $59 \%$ of the kinetic energy flux in the undisturbed flow through the same area as that of the turbine. However, in a more restricted flow (a small channel or where the turbines cover a significant part of the channel cross-section), the boundaries of the channel are likely to affect the fraction the kinetic energy that can be extracted. Under these circumstances, it has been concluded that the kinetic energy flux in the undisturbed flow is not a reliable estimate of the available power [28, 29].

Meanwhile, a growing interest in the economic potential for tidal energy during the 1990s and early twentyfirst century led to a number of resource assessments, oftentimes produced by private consultants, being pub- 
lished $[34,35,36,37,38,39,40]$. The purpose of most of these desktop studies was mainly to give a broad estimate of the potential from a large number of sites to aid in strategic decision-making regarding policies or future investments in tidal energy. This called for an easy-touse methodology that could be implemented for all sites. Hence, in many cases, in contrast with the findings in for instance [28, 29], the kinetic flux through the channel cross section has been used as a measure of the available power regardless of the local bathymetry. As discussed in section 4, this has also been the case in recent resource assessments in Norway. For a more in-depth review of previous international resource assessments, see [41].

\section{Oceanographic description of Norway}

Norway is situated in the western part of Scandinavia at $58^{\circ}-71^{\circ} \mathrm{N}$, characterized by the numerous fjords spread all along the coastline, originating from the end of the ice age. Although the coastline is $2500 \mathrm{~km}$ long as the crow flies, the total length of the coast is $83000 \mathrm{~km}$ including all the fjords and islands. Beyond the visual beauty of the fjords, oceanographers have for many years taken an interest in studying the physical oceanic processes of the fjords and the shelf areas in Norway. Much of this research has had the purpose of mapping fish species and their spawning areas $[42,43]$. The seafood industry is one of the major industries in Norway and has the second largest export in the world ${ }^{3}$. Especially important fishing areas are the northwestern and northern parts of Norway, including the areas around the Svalbard islands at $76^{\circ}-81^{\circ} \mathrm{N}$ (see Fig. 1). However, studies of Svalbard have focussed not only on oceanic processes regarding the marine life, but on the oceanic circulation around the islands, due to it being of major importance to the global climate [44, 45]. Altogether, the physical processes involved in the oceans around Norway are thus well known.

The aim of this section is to give a review of the hydrography and coastal structure of the coast of Norway. Although there are many interesting aspects of the circulation in Norwegian waters, this section is limited to the surface water masses and currents. The description includes the oceans surrounding Norway, the varying structure of the continental shelf, and the propagation of the tidal wave. Some areas are of particular interest and are therefore described in further depth.

\subsection{Oceans around Norway}

The coastline of Norway borders several oceans, whose hydrography and bathymetry influences the overall coastal current pattern. To the south lies the Skagerrak (see Fig. 1), which is the eastern part of the North Sea and through which the brackish water of the Baltic Sea passes. The circulation in the Skagerrak is cyclonic with a westward current along the southern end of Norway. The current is partly driven by the mixing of brackish outflow from the Baltic Sea and high saline deep-water as described in [46, 47].

Compared to the North Sea, the Skagerrak is deep due to a depression in the sea floor down to $700 \mathrm{~m}$ [46]. The sea-floor depression that runs from Skagerrak up along the Norwegian coast to the $62^{\circ} \mathrm{N}$ latitude is called the Norwegian Trench. The North Sea, in between Norway and Great Britain, is shallow with a mean depth of $100 \mathrm{~m}$, but is deeper (300-400 m) along the Norwegian coast due to the presence of the Norwegian Trench. At $62^{\circ} \mathrm{N}$ the North Sea segues into the Norwegian Sea and the trench continues into the continental slope. Being a part of the North Atlantic Ocean, the hydrography in the Norwegian Sea is to a large extent influenced by warm water from the Norwegian North Atlantic Current (NAC) that is an extension of the Gulf Stream. According to the Norwegian Pilot (DNL) ${ }^{4}$ [48], this is the reason coastal areas even at $68^{\circ} \mathrm{N}$ are ice-free during winter.

The westward coastal current encountered in the Skagerrak flows north along the Norwegian coast. The current is referred to as the Norwegian Coastal Current (NCC), consisting of Norwegian coastal water (NCW) and Atlantic water (AW). NCW appears close to the coast and is recognized by low salinity and cold temperature, being a result of large amounts of freshwater runoff from the fjords. AW is warmer and saltier and comes into the North Sea rounding the Shetland and Orkney Islands. AW is transported into the Norwegian Sea by the NAC. At $63^{\circ} \mathrm{N}$ the NCC splits in two, one branch joining the NAC and the other continuing along the coast in the shape of a coastal jet [49]. As the coastal jet moves northward, it mixes with AW and its salinity increases on the way.

From $62^{\circ} \mathrm{N}$ latitude to the Lofoten islands (see Fig. 2), the continental shelf has a mean width of more than $200 \mathrm{~km}$ to the $500 \mathrm{~m}$ isobath [43]. As the NCC reaches Vestfjorden, it again divides in two where one branch integrates in the circulation of Vestfjorden and one travels north along the outside of Lofoten [50].

At $70^{\circ} \mathrm{N}$, the continental slope continues north towards Svalbard, and the NAC splits with one branch following the shelf slope. The other branch moves eastward, parallel to the Norwegian coast, into the Barents Sea [42]. North of Norway lies the Tromøflaket, where depths are around $400 \mathrm{~m}$. Here the NCC is wide, still following the coastline while covering a large part of the Tromøflaket.

The circulation around Svalbard is more complex involving both AW and Arctic water, the former being warmer and saltier. The two distinctly different water masses are separated by the polar front south of Svalbard. The most important currents involved in the circulation around Svalbard are the West and East Spitsbergen Currents (WSC and ESC, respectively). The latter

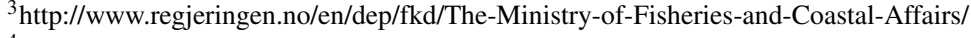

${ }^{4}$ Den Norske Los
} 


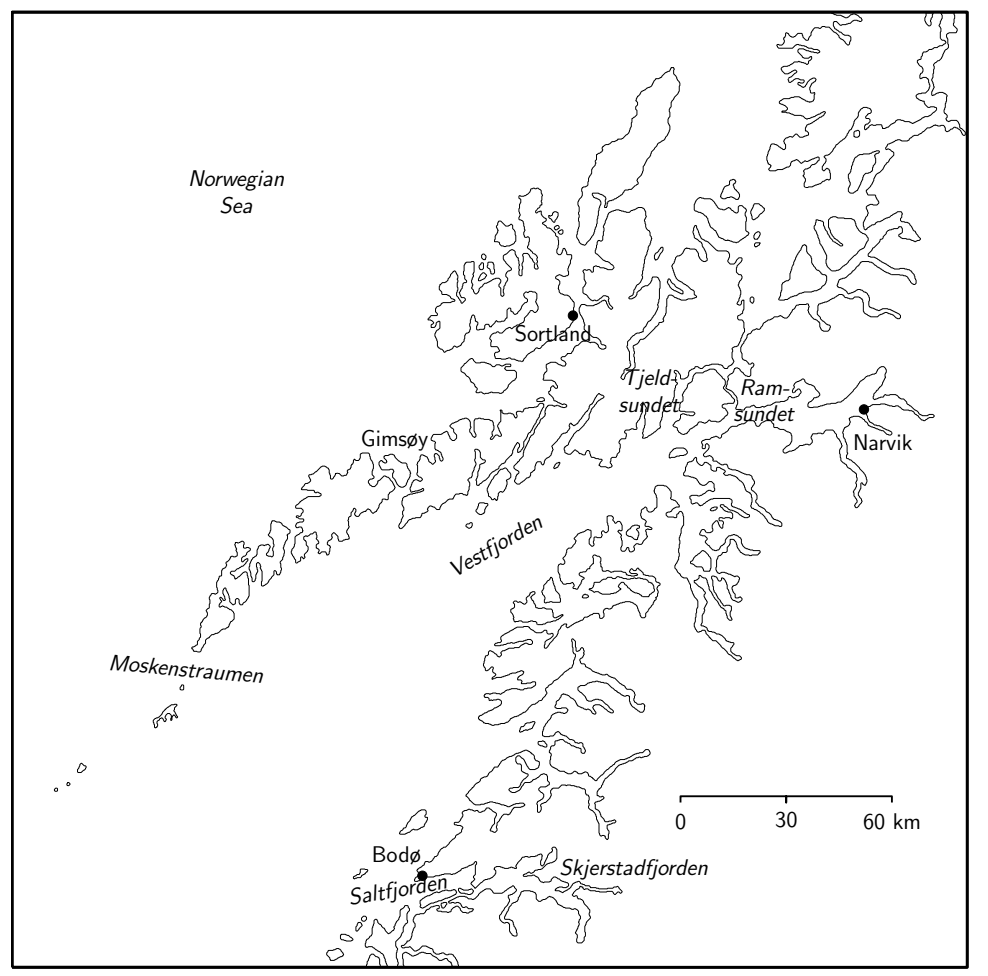

Figure 2: A map of the Lofoten Islands

consists of Arctic water and is renamed the Bear Island Current followed by Sørkappstrømmen as it moves along the eastern and southern shore of Svalbard. The WSC is a fraction of the NAC moving northward [48, 51].

\subsection{Tides}

The coastline of Norway is strongly affected by tides. Apart from extreme low pressure occasions, tides are the dominant contributor to sea level variations along the Norwegian coast.

The tidal wave propagates along the eastern borders of the Atlantic Ocean. As it reaches the northernmost tip of Great Britain, only a fraction of the wave moves eastward into the North Sea. It is reflected when it arrives in coastal areas, and the interaction between the incoming wave and the one reflected from the coast results in a tidal amplitude of only a few decimeters along the west coast of Sweden and south coast of Norway [52]. However, although the tides are modest, weather related effects on the water level in the south are large. The maximal tidal range (HAT-LAT ${ }^{5}$ ) is $72 \mathrm{~cm}$ in Oslo, but the maximum observed sea level range is $308 \mathrm{~cm}$. In [53], an extreme low pressure area was reported to have caused the water level to rise $2 \mathrm{~m}$ in 5 hours. The modelled volume flux through the strait of Drøbaksundet in Oslo indicated that the velocity could have been $5 \mathrm{~m} / \mathrm{s}$. Other similar effects were reported in [54], where the amplitude of a sea level oscillation was $0.8 \mathrm{~m}$ along the west coast of Norway, triggered by spatial and tempo- ral variations in the atmospheric forcing during a storm event.

The main part of the tidal wave departing north Great Britain continues over the continental shelf west of Norway, propagating northward along the Norwegian coast as a Kelvin wave [42]. The shallower depths in the central parts of Norway enhance the amplitude of the tidal wave. In Bodø south of Lofoten, the maximum tidal range is $333 \mathrm{~cm}$ with a mean spring tidal range of $236 \mathrm{~cm}$ [55]. Here the difference between Highest Water Level (HWL) and HAT is less than in the south, as can be seen in Fig. 3 .

The tidal wave is dominated by the semi-diurnal component M2. However, Vestfjorden acts as a trap of the semi-diurnal component and a strong sea level gradient appears between the area outside of Lofoten and Vestfjorden [56]. North of Lofoten the shelf-waves split up, one branch following the continental slope towards Svalbard, and the other continuing along the coast where it slows down and increases in height as it approaches Vardø (see Fig. 3).

\subsection{Sites of interest for tidal current energy}

Tidal amplitude, narrow constrictions, topographic effects, and natural period of standing waves in a basin are all important for the evolution of strong tidal currents. Narrow and shallow inlets lead to head difference and phase delay between the tidal waves at either ends of the channel. If the natural period of the basin, determined by

\footnotetext{
${ }^{5}$ Highest/Lowest Astronomical Tide
} 


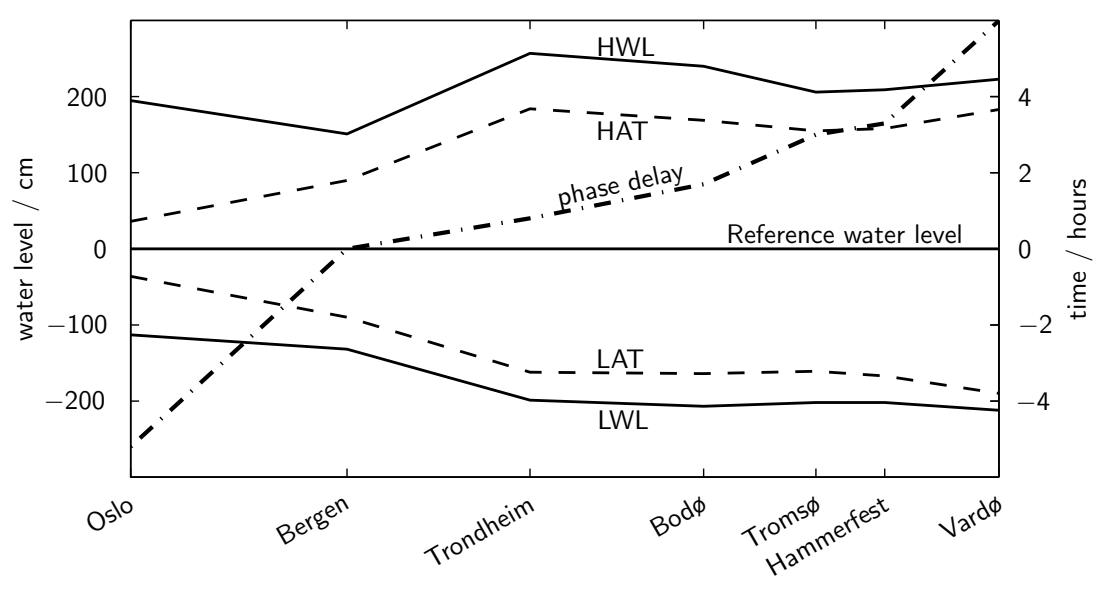

Figure 3: Sea level shown as Highest and Lowest Water Level (HWL/LWL) and Highest and Lowest Astronomical Tide (HAT/LAT) in comparison with the reference (mean) water level $[\mathrm{cm}]$. Also in the figure are the variations in time [h] for the occurrence of high/low water, where time for high water is taken as 0 in Bergen. Data from DNL [52]

its dimensions, is close to the tidal period the tidal range is enhanced due to resonance effects. The largest tidal range in the world, $16 \mathrm{~m}$, is possibly that in the Bay of Fundy in Canada, where the natural period of the basin is around 13 hours, close to the tidal period of the main semi-diurnal component which is 12.42 hours $^{6}$.

In Norway, strong tidal currents are common in the north partly due to the increase in tidal range with latitude. The Moskenstraumen (sometimes Moskstraumen) tidal current in Moskenes Sound (see Fig. 2) has been world-famous for centuries, due to the mythical capacity of the Maelstrom vortex to pull ships down under the sea and swallow them up [57]. The surface current reportedly reaches a strength of $5 \mathrm{~m} / \mathrm{s}$ at times according to DNL [48], and it is occasionally strong enough to appear in satellite SAR images [58]. The mechanism behind the current is the water level difference between Vesterålen (to the west of Lofoten) and Vestfjorden (to the south), which creates a pressure gradient. In [57, 59] it was concluded that the level difference arises due to two combined effects; the narrowing of the continental shelf from being relatively wide to very narrow west of Lofoten, and a tidal choking phenomenon caused by the blocking effects of the group of islands and the shallow bank at the tip of Lofoten.

Current measurements of Moskenstraumen are scarce. However, in DNL [48] current measurements are presented for several sites in channels running through the Lofoten islands. One example is Gimsøystraumen, a channel in the middle of Lofoten, where the measured maximum spring tidal velocity was $2.3 \mathrm{~m} / \mathrm{s}$ occurring one hour after high water. In Sandtorgstraumen, a channel closer to the mainland, the measured spring tidal velocity was above $2 \mathrm{~m} / \mathrm{s}$ [60]. The forces behind these currents are sea level differences between the areas north and south of Lofoten.

The Saltstraumen current, located on the mainland

\footnotetext{
${ }^{6}$ http://www.srh.noaa.gov/jetstream/ocean/fundy_max.htm
}

coast at $67^{\circ} \mathrm{N}$, is presented in [48] as having a spring tidal current velocity of around $4 \mathrm{~m} / \mathrm{s}$, but it is said to be considerably higher during certain weather conditions. The strong current in the channel arises due to the geometry of the narrow channel causing hydrodynamic drag [61], which leads to a phase delay in time and a strong dampening of the tide. According to [61], the major tidal constituent is delayed $114 \mathrm{~min}$ and reduced by a factor of 0.61 from Bod $\varnothing$ (see Fig. 2) to Finneid (located inside of Saltstraumen).

Because of the large amount of fjords in Norway, it is likely this tidal choking phenomenon is the most common cause of strong currents. Another site where this occurs is in Trondheimsleia, the approaches to Trondheim (see Fig. 1), where the peak tidal current velocity was on the order of $0.5 \mathrm{~m} / \mathrm{s}[62,63]$. Since the tidal amplitude increases with latitude, the strongest tidal currents are found in the Lofoten area and further north along the coastline, far surpassing the velocities in Trondheimsleia.

\section{Numerical models of tidal cur- rents in Norway}

Over the years, a fair amount of numerical modelling work has been done regarding tidal flow along the Norwegian coast and around Svalbard. This work has been aimed mainly towards such uses as understanding the implications of underwater currents for transport of biological and chemical tracers (cod eggs, etc.) [64] and the prediction of surface currents and depth variations for the benefit of shipping [54, 63]. Relatively little published work has been concerned with tidal energy assessments or related issues. While not originally intended for tidal energy use, many of the models developed still ought to be suitable or at least adaptable for this purpose. 
In the following section, we shall take a look at a few numerical models used for different geographical locations in Norwegian waters.

\subsection{The University of Oslo Model}

A numerical model developed at the Department of Mathematics at the University of Oslo has been used to simulate tidal flow in several locations along the Norwegian coastline. Among them is the Moskenstraumen current (see section 2.3), studied by Gjevik et al. [59]. The model included the semi-diurnal components $M_{2}, S_{2}$, and $N_{2}$ as well as the diurnal component $K_{1}$, and the authors claimed fair agreement between calculated phases and amplitudes and observed values provided by the Norwegian Hydrographic Service. Although some large eddy-like structures were observed in the flow, nothing even remotely similar to the ship-swallowing Maelstrom of the ancient tales appeared in the simulations. With a view to studying the importance of Moskenstraumen for cross-shelf transportation of cod eggs, larvae, etc. from an environmental perspective, Ommundsen [64] used the flow data from [59] to track particle drift due to the tidal events.

The authors of [59] and [64] used the same numerical model to study the tidal flow in the entire Lofoten area in [56]. The simulation spanned an area roughly $350 \mathrm{~km}$ by $350 \mathrm{~km}$ out of which approximately 3/4 were sea and 1/4 land. The spatial grid resolution was $500 \mathrm{~m}$, which must be considered quite fine under the circumstances. The tidal motion was tracked from ocean boundary conditions taken from larger-scale models and into relatively narrow gaps and sounds among the islands of the archipelago. Certain non-linear effects, such as turbulence and flow separation, were ignored in the model. Among the results reported were current fields for Moskenes Sound, Tjeldsundet, the Sortland channel, and the Gimsøy channel. These figures were correlated with data from [48] and found to be in general agreement, especially with regard to temporal shift in the current throughout the tidal cycle. While the geographical positions chosen for evaluation in [56] may be obviously unsuitable for tidal energy extraction - they seem to have been selected mainly due to their importance as local shipping lanes-, the potential of the numerical model for use in evaluation of possible tidal energy sites should nevertheless be clear.

The numerical model, as used in [59] and [64], neglected non-linear advection terms. These were included by Hjelmervik et al. [65], and the model was used with a grid resolution of $25-50 \mathrm{~m}$ to simulate the tidal flow in Tjeldsundet and Ramsundet [60]. The model was still depth-integrated, meaning results for current speeds etc. were averaged from bottom to surface. In this way, any stratification in the water due to e.g. salinity or temperature was not modelled; the authors assumed that in narrow, shallow sounds turbulent mixing would do away with stratification, and thus the simplification was felt to be justified. The purpose of the study reported in [60] was primarily navigational, and the surface tidal currents predicted by the model were incorporated into the navigational systems used by the Norwegian Navy during an exercise in early 2006.

Moe et al. [66] applied the model used in [56] to study the tidal flow along the coast of Møre and Trøndelag, two provinces located some $500 \mathrm{~km}$ south of Lofoten (see Fig. 1). The computational domain was of similar geographical size as in [56], as was the spatial grid resolution. The justification for the study was mainly interest from the petroleum industry and navigational considerations. The aquaculture industry (fish farming) was speculated to be a potential future user of the model, mainly to study the drift and dispersion of passively floating particles in the water, as in [64].

Gjevik et al. [63] again used the model to simulate tidal flow in the approaches to Trondheim (Trondheimsleia) in order to provide data for navigational chart systems. An analysis of measurements of current and sea level in the same area had been done by Orre et al. [62]. Again, a depth-integrated model using the shallow-water equations will not consider stratification, but for navigational purposes knowledge of local depth and surface current will usually be sufficient. The same model, but with a $50 \mathrm{~m} \times 50 \mathrm{~m}$ grid resolution, was again employed by Orre et al. [67] to study chaotic dispersion in the Trondheim Fjord. Vertical shear was assumed to be negligible, at least in winter, and focus was placed on surface dispersion.

For completeness it should be mentioned that Gjevik and his co-workers also modelled tidal flow and/or effects, sometimes in combination with weather changes, in the Oslo Fjord [53], the Barents Sea [68], and the North Sea [54]. It appears the models used for these papers were earlier versions of the model described above.

\subsection{The Bergen Ocean Model}

Eliassen et al. [61] used a numerical model known as the Bergen Ocean Model (BOM), developed at the University of Bergen [69], to study the circulation in Saltfjorden and Skjerstadfjorden (see section 2.2). These are situated south of Lofoten, close to the town of Bod $\varnothing$ (see Fig. 2). While these fjords were actually included in the area covered by the simulations of [56], they lie on the mainland coast and are not part of Lofoten. The two fjords are connected by Saltstraumen, where the tidal current will peak at over $4 \mathrm{~m} / \mathrm{s}$ and be consistently stronger than $3 \mathrm{~m} / \mathrm{s}$ in either direction during $2 / 3$ of the tidal cycle [48]. This current was observed in the numerical model, even though the primary purpose of the study was not to investigate tidal currents or their potential for energy extraction.

The BOM is of a model type known as $\sigma$-coordinate, which is a poular type for ocean models. The main advantage of $\sigma$-coordinate models is their ability to resolve bottom boundary and surface layers, however, the models may exhibit erroneous internal pressure gradients under certain circumstances such as steep bottom topog- 
raphy [70]. The BOM implementation makes use of the hydrostatic and Boussinesq approximations ${ }^{7}$, both widely used in various ocean models [69]. The hydrostatic approximation is not necessarily valid when there are significant vertical variations in flow speed and stratification is weak. For in-shore tidal flow in constrained conduits such as fjords with varying depth and width, non-hydrostatic effects may be of considerable importance. The BOM was further developed by Heggelund et al. [71] to include non-hydrostatic effects.

Skogseth et al. [72] nevertheless retained the hydrostatic approximation when applying the BOM to study the circulation in Storfjorden in Svalbard (see Fig. 1). In this study, tidal currents of nearly $2 \mathrm{~m} / \mathrm{s}$ were observed in Heleysundet and Freemansundet during ice-free conditions, although it was noted that the flow should be significantly damped when the sounds are covered by ice. The tidal current off Sørkapp reached $1.3 \mathrm{~m} / \mathrm{s}$ according to the model, probably due to topographical enhancement. Again, the investigation was not aimed at tidal energy assessment, but the BOM ought to be possible to put to such use as well.

\subsection{Other models}

Ellingsen [73] applied the Navy Coastal Ocean Model (NCOM) developed by the U.S. Naval Research Laboratory [74] to the Trondheim Fjord to study internal tides and other phenomena in the fjord. The spatial grid resolution was varied between $100 \mathrm{~m}$ and $500 \mathrm{~m}$. The NCOM is said to be particularly suited for modelling the Trondheim Fjord and to handle the inclusion of river and runoff inflows well. The model is based on the hydrostatic and Boussinesq approximations. For the Trondheim fjord, modelling of heat flux between ocean and atmosphere was specifically added to the model [73].

The study was aimed at understanding the circulation in the fjord and the spread and mixing of freshwater from rivers and runoff. While the importance of tides for energy influx to the fjord was recognised, no effort was dedicated to modelling tidal currents specifically [73].

In addition to the work reviewed above, there has been a substantial amount of numerical work published on tidal ocean currents in the vicinity of Norway. These are, however, of relatively little immediate interest from a tidal energy extraction point of view and are therefore considered to be outside the scope of the present review.

\section{Tidal current resource assess- ment in Norway}

There has been little information published regarding tidal energy as a renewable resource in Norway. In inter- national resource assessments such as [35, 36], the Norwegian coastline has largely been ignored even though there have been several reports on strong currents in Norway, as mentioned in sections 2 and 3. However, in recent years the interest for offshore renewables has increased in Norway, and a number of estimates of the tidal energy resource have appeared. In this section, two published resource assessments will be examined. The first report to be published was a master's thesis project in 2006 [75]. This was then followed in late 2007 by an assessment [76] prepared by private consultants for Enova SF, a public enterprise owned by the Norwegian Ministry of Petroleum and Energy. Additionally, as a part of the present review, a comparative study including a large number of sites has been performed to complement the two published assessments (see Table 3, App. A).

As with previous resource assessments, there is a considerable uncertainty connected to these desktop studies as they are mainly based on secondary material prepared for other uses than assessing the tidal energy resource. For instance, the tidal current velocity is collected from sometimes rather rough values given in pilot books. The problem is subsequently amplified when the velocity is cubed to estimate the kinetic energy, leading to large relative errors.

All three assessments are mainly based on the same data. The current velocities are gathered from DNL $[48,52,77,78,79,80,81]$, and depth and width for each site are estimated from digital sea charts available from the Norwegian Coastal Administration ${ }^{8}$. It is only the matter of interpreting the pilot books and sea charts that differs among the estimates. As mentioned in [75], the velocities given in DNL sometimes carry little scientific value. In some cases the velocity is measured, and in other cases the velocity is estimated based on visual observation or collected from anchored rigs. From DNL, it is not always clear if the velocity at a certain site has been measured or estimated. Furthermore, it is not stated whether the velocity is the highest spring speed or a mean value. Having said that, it is important to note that the velocity data provided in DNL is interpreted as the mean maximum spring speed (MMSS) in the resource assessments. It is also assumed in the assessments that the currents vary sinusoidally at all sites. Another important issue is that the velocity is strongly dependent on the cross-sectional area along the channel [82], and it is not clear from DNL precisely which location at a given site the velocity figures refer to. Furthemore, the drag of the support structures (which is further discussed in [83]) is neglected when evaluating the technical and economical resource. All in all, these issues add up to the large uncertainty in the available resource assessments.

In tidal current resource assessments, the resource is

\footnotetext{
${ }^{7}$ Hydrostatic approximation. The assumption that the pressure at a given point is due only to the weight of the water above it; considered to be valid when vertical accelerations are small in comparison to gravitational acceleration.

Boussinesq approximation. The assumption that density variations are too small to affect inertia but may be important with regard to buoyancy effects; considered to be valid in most ocean flows.

${ }^{8} \mathrm{http}: / /$ kart2.kystverket.no/
} 
Table 1: The number of sites and calculated resource as presented in the three different resource assessments.

\begin{tabular}{lccc}
\hline & Fröberg [75] & Enova SF [76] & Present study \\
\hline No. of sites & 12 & 22 & 104 \\
Theoretical resource & $2.3 \mathrm{TWh}$ & - & $17 \mathrm{TWh}$ \\
Extractable resource & $0.23-1.1 \mathrm{TWh}$ & - & - \\
Technical resource & $0.18-0.89 \mathrm{TWh}$ & $>1 \mathrm{TWh}$ & - \\
Economical resource & $0.16-0.82 \mathrm{TWh}$ & $<1 \mathrm{TWh}$ & - \\
\hline
\end{tabular}

sometimes given as theoretical, extractable, technical, or economical. The theoretical resource is often defined as the kinetic energy available in the free flowing water throughout the whole cross-section on a site. How much of this energy that could be extracted is then labelled the extractable resource. In its purest form, the extractable resource shows the maximum amount of energy that could physically be extracted at a site. Quite frequently, however, concerns for the natural and social/economic environment are included when estimating the extractable resource. How large a fraction of the kinetic energy in the undisturbed tidal current that can be extracted without creating unacceptable ecological impact or reduction in the current speed is sometimes called the significant impact factor, or SIF [36]. Similarly, there might be other technical and economical constraints depending on the chosen site and technology that would be included in an analysis of the technical and economical resource. From here on, the theoretical resource is discussed unless otherwise indicated.

The method used to attain the theoretical resource in [75] and in the present study is similar to that described in [36, 84]. It is not explicitly stated in [76] that this is the method that is used. However, a quick recalculation using the method from [75] yields the same results as presented in [76]. It is a simple and easy-touse model with its limitations and flaws (see e.g. [41] for more details). Based on the mean maximum spring speed (MMSS) and cross section at a site, the kinetic energy flux is calculated. With factors to describe the characteristics of the tide-such as the relationship between the first and second tide, spring and neap tide, assumed velocity profile, etc.- - the annual energy is calculated. As mentioned earlier, this approach to calculating the theoretical resource is sensitive to errors in the input data for MMSS, since the cube of the speed is used for the energy estimate. With this in mind, 12 sites were evaluated in [75], 22 sites in [76], and 104 sites in this study (see Table 1).

In the present study, only the theoretical resource is considered (see Table 1), as the extractable, technical, and economical resources are expected to be both site specific and technology dependent. Hence, the results from this comparative study should only be seen as a rough indication of the size of the resource and how many sites that can be found in DNL. In [75], 58 sites are listed as interesting, but the theoretical resource is only evaluated for 12 sites with a MMSS of $2 \mathrm{~m} / \mathrm{s}$ or more and a minimum depth of $6 \mathrm{~m}$, yielding $2.3 \mathrm{TWh}$. From this result the theoretical resource for Norway as a whole is estimated to 3.4-6.8 TWh. The extractable resource is based on an assumed SIF of $10-50 \%$ due to the large uncertainity connected to the concept of SIF. As discussed in section 1.2, both analytical and numerical models have shown that the limit of energy extraction can vary significantly. Although most of these are general models, no known site specific investigation regarding the limit of energy extraction has been published for Norway. The Enova SF study [76], on the other hand, does not include the theoretical or extractable resource. Rather, the technical resource is evaluated for 24 sites taking into account the efficiency of the marine current energy converter and the fact that not all of the crosssectional area can be utilized. The assumptions include covering $50 \%$ of the cross-section, a $40 \%$ total system efficiency, and 3500 hours of operation throughout the year. Sites with a maximum velocity above $1.5 \mathrm{~m} / \mathrm{s}$ have been considered and two of the 24 sites have been excluded as they were considered too deep to be developed. With these constraints, the technical resource is estimated to slightly above 1 TWh and the expected economical resource to slightly below $1 \mathrm{TWh}$.

To see if it is possible to distinguish any general characteristics for the Norwegian resource, all the sites in the three resource assessments have been organized according to depth and velocity in Table 2. Unsurprisingly, the lion's share of the resource is found in deep sites with a high velocity. However, it is also clear that there is a considerable number of smaller sites that could be developed. Given the relatively early stage of development of present-day tidal current energy conversion technology, it is not self-evident that the large sites would also automatically be the most economically attractive. In time, there might emerge different technical solutions for sites of different depth and velocity. Furthermore, the cost of deployment at different depths and distance to the nearest grid connection point could be vital factors determining if a site is economically viable or not. This has not been considered in these resource assessments.

It should be noted that the sheer size of Moskenstraumen has a large impact on the results shown in Table 2. Moskenstraumen is included in [76] with a maximum velocity of $2.5 \mathrm{~m} / \mathrm{s}$. It accounts for $760 \mathrm{GWh}$ or roughly $65 \%$ of the total resource, which also explains why $79 \%$ of the resource in [76] is found in the velocity interval of 2-3 m/s. In the present study, however, Moskenstrau- 
Table 2: A comparison of how the resource is distributed among different velocity and mean depth intervals in the three resource assessments. The number of sites is given for each interval followed by the contribution to the total resource as a percentage.

\begin{tabular}{lccc}
\hline No. of sites with & Fröberg [75] & Enova SF [76] & Present study \\
\hline MMSS above $3 \mathrm{~m} / \mathrm{s}$ & $3(41 \%)$ & $4(6 \%)$ & $28(68 \%)$ \\
MMSS of 2-3 m/s & $9(59 \%)$ & $11(79 \%)$ & $39(26 \%)$ \\
MMSS below 2 m/s & - & $9(15 \%)$ & $37(6 \%)$ \\
mean depth of more than 40 m & $1(24 \%)$ & $11(85 \%)$ & $15(59 \%)$ \\
mean depth of 20-40 m & $5(52 \%)$ & $11(13 \%)$ & $17(28 \%)$ \\
mean depth of less than 20 m & $6(24 \%)$ & $2(2 \%)$ & $72(13 \%)$ \\
\hline
\end{tabular}

men is included with a maximum velocity of $3 \mathrm{~m} / \mathrm{s}$ contributing roughly $27 \%$ of the total resource; hence the larger share of the resource in the velocity interval above $3 \mathrm{~m} / \mathrm{s}$ in this study compared to [76]. It is also important to note that Moskenstraumen is not included among the 12 sites evaluated in [75].

To summarize, the data used in the three resource assessments has limited scientific value and the methodology used results in large relative errors. The results presented could however give a rough indication of the size and characteristics of the Norwegian tidal energy resource.

\section{Prototypes and experiments}

Norwegian industry is renowned for its knowledge in offshore engineering, and in recent years several projects in ocean energy have been initiated. Not much has been published regarding these projects, however, other than short notes in tidal current energy technology reviews such as $[6,85]$, probably because they are in early stages of development and mainly driven by private companies.

Perhaps the best known tidal current energy project in Norway is that of Hammerfest Strøm AS. The company was founded in 1997 and the largest owner Statoil brought in its expertise in offshore engineering. Hammerfest Strøm's first $300 \mathrm{~kW}$ prototype was deployed in Kvalsundet outside the town Hammerfest (see Fig. 1) in northern Norway in 2003. Since then, the company has reached an agreement to collaborate with ScottishPower with the intention to finalize a $1 \mathrm{MW}$ installation in $2009^{9}$.

The Norwegian utility company Statkraft AS has also shown interest in tidal energy. Statkraft have been working with Hydra Tidal Energy Technology AS to develop a floating, moored platform that holds two contrarotating turbines rated at $500 \mathrm{~kW}$ each. The first demonstration plant, called "Morild", was planned to be deployed in Kvalsundet in Troms $\varnothing$ (a different site from the Hammerfest Kvalsundet). So far, an exploratory survey on possible environmental impact at the site has been published [22]. Furthermore, the strucural mechanics of the floating system and the importance of wave induced loads have been discussed in [86]. Other projects to be noted in [76] are a Darrieus turbine developed by Water Power Industries $\mathrm{AS}^{10}$ and a horizontal axis turbine developed by TideTec AS. However, TideTec had applied for permission to build a pilot plant in Sundstraumen (close to the well known Saltstraumen; see Fig. 2), but their application for a $600 \mathrm{~kW}$ prototype was turned down by the Norwegian Water Resources and Energy Directorate in 2007, as the area is planned to become a marine protected area [87].

\section{Discussion}

The geographic and oceanographic conditions for tidal current power generation are favourable in Norway. The extensive coastline with its numerous fjords, islands, sounds, and inlets makes for strong tidal currents with large flux volumes. Another beneficial effect of the long coastline in combination with the propagation of the tidal wave along the coast is the tidal phase lag due to geographical location. This phase lag provides an opportunity to distribute the tidal energy load on the national grid over time, thus in part mitigating the otherwise intermittent character of tidal energy.

In section 3, several numerical models of tidal flow in Norwegian waters were reviewed. While none of these models were aimed at calculating the tidal energy in the flow, they are clearly quite advanced and indicate the high level of understanding of ocean flow simulations that can be found in Norwegian universities. Both the Bergen Ocean Model [61, 69] and the model developed at the University of Oslo $[56,66]$ have been used to calculate the velocity and volume flux of tidal flow through narrow sounds. The models probably require some further development before they can be applied to tidal energy assessments. The next step, to calculate the theoretical tidal energy resource, should not be insurmountable. However, the theoretical resource on its own is probably a poor indicator of how much energy from a site can in practice be converted and delivered to the electricity grid (cf. section 1.2). For useful estimates of the extractable

\footnotetext{
${ }^{9} \mathrm{http}: / /$ www.hammerfeststrom.com/

${ }^{10}$ http://www.wpi.no/
} 
resource, it will also be necessary to include the effects of energy extraction in the calculations (i.e. to include the turbine farm in the model).

Such calculations should in turn provide better input for resource assessments such as those of references $[75,76]$ and that performed for the present review. As was pointed out in section 4, the unscientific nature of velocity data taken from pilot books is a major contributor to the limited reliability of and large variations in results among these studies. This is not because the figures in the pilot books are wrong, but because the accuracy and stringency required in such data is very much higher, and different in character, when trying to estimate an energy resource as compared to when navigating a vessel into a specific harbour. Furthermore, the appearance of tidal data for a particular site in a pilot book indicates that the site is used for shipping, commercial or otherwise, which in turn shows the importance of considering conflicts with other users. With proper numerical models available, the flow in sounds and fjords not covered by DNL could be simulated, which ought to give considerably more relevant figures from an energy point of view.

All three resource assessments suffer from other shortcomings, beside the input data. As has been mentioned, the methodology used is sensitive to relative errors, and it is questionable whether the theoretical resource-the kinetic energy in the undisturbed flowcan be used as a measure of the extractable potential. None of the assessments seem to have considered conflicts with other users. Norway has a lot of offshore industry; shipping, fishing, and aquaculture to name but a few. The establishment of tidal power plants may very well interfere with the interests of any of these groups, and this has to be taken into consideration when assessing the extractable resource. All three studies also assumed that the resource at one site is not affected by energy extraction at sites nearby, which is not necessarily true.

Two of the resource assessments [75, 76], looking at only 12 and 22 sites, respectively, have concluded that the annual extractable resource is on the order of $1 \mathrm{TWh}$. However, due to the complex coastline in Norway, it is likely that there are many more sites that could be considered. In the study of the present review, more than 100 interesting sites have been highlighted, yielding a theoretical resource on the order of 17 TWh. How much of this potential that could be utilized is still unknown, and based on what was said above it should be clear that further study of the resource potential is necessary. However, that there is in fact a considerable tidal energy resource in Norwegian waters should be beyond dispute.

The importance of renewable energy sources is on the rise. Norway has a solid hydro power base to build on, but the almost total reliance on a single source of electricity is in itself disadvantageous. Hydro power is sensitive to changes in precipitation, and while there is still some room for further development in Norway, environmental concerns will eventually limit this resource as well. Among new sources of electricity, land based wind power exhibits the highest degree of technological maturity. Offshore wind power is still in relatively early stages of development, but benefits from the experience of the established wind power industry. Wave power rates highly in resource assessments, and while there are as yet no commercial wave power plants in operation in Norway, the technology is quickly being developed around the world. Tidal power is the third ocean power category, after offshore wind and wave power.

Against this background, tidal current energy conversion ought to be an interesting option for Norway. The main reasons, not necessarily in order of importance, are:

- Norway possesses a palpable tidal energy resource, although assessments to date of its extent are imperfect.

- Tidal currents are extremely predictable and reliable (compared to e.g. wind or waves).

- The length of the Norwegian coastline creates a tidal phase lag between different geographical locations. This phase lag could be exploited to even out the load over time.

- The abundant hydro power resource can be used to mitigate the intermittency of tidal power.

- There is a political will in Norway to increase the fraction of renewable energy, while at the same time decreasing the reliance on hydro power. There is also a movement to export electricity to other European countries.

- Norwegian industry has considerable experience in offshore construction work, which could be put to use in tidal power plant development.

In the end, it is not a matter of either hydro power or ocean power, nor of either wind power or tidal current power. It is a matter of a little bit of each. In order to ultimately decrease society's dependence on fossil fuels, all renewable energy sources have to be considered. Based on the conditions and previous work reviewed above, it should be clear that tidal currents are potentially very important to Norway from an energy supply point of view.

\section{Acknowledgements}

The authors gratefully acknowledge the financial support of Uppsala University, Vattenfall AB, the Swedish Agency for Innovation Systems (VINNOVA), the Swedish Energy Agency (STEM), Ångpanneföreningen's Foundation for Research and Development, the J. Gust. Richert Foundation for Technical Scientific Research, CF's Environmental Fund, and Statkraft AS. 


\section{References}

[1] Energy in Norway, Norwegian Water Resources and Energy Directorate, available online: http://www.nve.no/ (2007).

[2] J. Løvseth, The renewable energy potential of Norway and strategies for its development, Renewable Energy 6 (3) (1995) 207-214.

[3] J. Alvsvåg, Arealkonflikter ved etablering av vindkraftverk og bølgekraftverk i Norskehavet, Tech. Rep. 117887/1-08, Norwegian Ministry of Petroleum and Energy (April 2008).

[4] Thorium as an energy source-opportunities for Norway, Thorium Report Committee, Research Council of Norway (February 2008).

[5] Vindkraft offshore - industrielle muligheter for Norge, Energy Council of Norway (May 2008).

[6] Renewable energy, SWECO Grøner, Norwegian Water Resources and Energy Directorate, Enova SF, Research Council of Norway, Innovation Norway, available online: http://www.renewableenergy.no/, ISBN 978-82410-0637-1 (March 2007).

[7] H. Andre, Ten years of experience at the La Rance tidal power plant, Ocean Management 4 (1978) 165-178.

[8] J. P. Frau, Tidal energy: Promising projects. La Rance, a successful industrial-scale experiment, IEEE Transactions on Energy Conversion 8 (3) (1993) 552-558.

[9] R. H. Charlier, Forty candles for the Rance River TPP tides provide renewable and sustainable power generation, Renewable \& Sustainable Energy Reviews 11 (2007) 2032-2057.

[10] T. J. Hammons, Tidal power, Proceedings of the IEEE 81 (3) (1993) 419-433.

[11] J. H. Crothers, C. Little, C. Mettam, Evolution and change in the Bristol Channel and Severn Estuary: introduction to the proceedings, Biological Journal of the Linnean Society 51 (1-2) (1994) 1-3.

[12] M. Sathiamoorthy, S. D. Probert, The integrated Severn barrage complex: Harnessing tidal, wave and wind power, Applied Energy 49 (1994) 17-46.

[13] The Severn Barrage-definition study for a new appraisal of the project, UK Department of Trade and Industry, ETSU report no. T/09/00212/00/REP (January 2002).

[14] D. Kerr, Marine energy, Philosophical Transactions of the Royal Society A 365 (1853) (2007) 971-992.

[15] R. Bedard, Survey and characterization - tidal in stream energy conversion (TISEC) devices, EPRI TP-004 NA (November 2005).

[16] A. S. Bahaj, L. Myers, Analytical estimates of the energy yield potential from the Alderney Race (Channel Islands) using marine current energy converters, Renewable Energy 29 (2004) 1931-1945.

[17] P. L. Fraenkel, Marine current turbines: pioneering the development of marine kinetic energy converters, Proc. IMechE Part A: Journal of Power and Energy 221 (2007) 159-169.

[18] P. L. Fraenkel, Marine current turbines: Moving from experimental test rigs to a commercial technology, in: Proceedings of the 26th International Conference on Offshore Mechanics and Arctic Engineering, OMAE 2007, 2007, pp. 1-10, OMAE2007-29642.
[19] C. A. Douglas, G. P. Harrison, J. P. Chick, Life cycle assessment of the Seagen marine current turbine, Proc. IMechE Part M: Journal of Engineering for the Maritime Environment 222 (2008) 1-12.

[20] A scoping study for an environmental impact field programme in tidal current energy, Robert Gordon University, UK Department of Trade and Industry, ETSU T/04/00213/REP (2002).

[21] Scott Wilson, A. J. Downie, A review of possible marine renewable energy development projects and their natural heritage impacts from a Scottish perspective, Tech. Rep. F02AA414, Scottish Natural Heritage (2003).

[22] G. H. Systad, Ø. Aas-Hansen, J. O. Bustnes, P. A. Bjørn, Pilotanlegg tidevannskraft Kvalsundet. Statusbeskrivelse og mulige konsekvenser for naturmiljøet, Tech. Rep. Report 112, Norsk institutt for naturforskning, ISSN: 15043312 (2005).

[23] J. A. Clarke, G. Connor, A. D. Grant, C. M. Johnstone, Regulating the output characteristics of tidal current power stations to facilitate better base load matching over the lunar cycle, Renewable Energy 31 (2006) 173180.

[24] M. Leijon, H. Bernhoff, M. Berg, O. Ågren, Economical considerations of renewable electric energy productionespecially development of wave energy, Renewable Energy 28 (2003) 1201-1209.

[25] J. Hardisty, Power intermittency, redundancy and tidal phasing around the United Kingdom, Geographical Journal 174 (1) (2008) 76-84.

[26] I. G. Bryden, G. T. Melville, Choosing and evaluating sites for tidal current development, Proc. IMechE Part A: Journal of Power and Energy 218 (2004) 567-577.

[27] I. G. Bryden, S. J. Couch, ME1-marine energy extraction: tidal resource analysis, Renewable Energy 31 (2006) 133-139.

[28] C. Garrett, P. Cummins, The power potential of tidal currents in channels, Proceedings of the Royal Society A 461 (2005) 2563-2572.

[29] C. Garrett, P. Cummins, Generating power from tidal currents, Journal of Waterway, Port, Coastal and Ocean Engineering 30 (3) (2004) 114-118.

[30] J. Blanchfield, C. Garrett, P. Wild, A. Rowe, The extractable power from a channel linking a bay to the open ocean, Proc. IMechE Part A: Journal of Power and Energy 222 (3) (2008) 289-297.

[31] J. Blanchfield, C. Garrett, A. Rowe, P. Wild, Tidal stream power resource assessment for Masset Sound, Haida Gwaii, Proc. IMechE Part A: Journal of Power and Energy 222 (5) (2008) 485-492.

[32] L. S. Blunden, A. S. Bahaj, Initial evaluation of tidal stream energy resources at Portland Bill, UK, Renewable Energy 31 (2) (2006) 121-132.

[33] L. S. Blunden, A. S. Bahaj, Effects of tidal energy extraction at Portland Bill, southern UK, predicted from a numerical model, in: Proceedings of the 7th European wave and tidal energy conference, EWTEC 2007, Porto, Portugal, 2007, pp. 1-10.

[34] Tidal stream energy review, UK Department of Trade and Industry, prepared by Engineering and Power Development Consultants Ltd., ETSU-T-05/00155/REP (1993). 
[35] The exploitation of tidal marine currents, Tecnomare, IT Power Ltd., Ponte di Archimede and University of Patras, European Commission, final report EU-JOULE contract JOU2-CT94-0355 (1996).

[36] UK, Europe and global tidal stream energy resource assessment, Black \& Veatch Ltd. (September 2004).

[37] Tidal stream - phase II. UK tidal stream energy resource assessment, Black \& Veatch Ltd. (September 2005).

[38] Green energy study for British Columbia, phase 2: Mainland. Tidal current energy, Triton Consultants Ltd., prepared for BC Hydro (October 2002).

[39] The development and market potential for tidal current power in Scotland, Scottish Enterprise, Centre for Environmental Engineering and Sustainable Development, Robert Gordon University (2003).

[40] T. Whittaker, P. L. Fraenkel, A. Bell, L. Lugg, The potential for the use of marine current energy in Northern Ireland, UK Department of Trade and Industry, UK Department of Enterprise, Trade and Investment and Northern Ireland Electricity (June 2003).

[41] L. S. Blunden, A. S. Bahaj, Tidal energy resource assessment for tidal stream generators, Proc. IMechE Part A: Journal of Power and Energy 221 (2007) 137-146.

[42] J. Skardhamar, H. Svendsen, Circulation and shelf ocean interaction off north Norway, Continental Shelf Research 25 (2005) 1541-1560.

[43] R. Sætre, Features of the central Norwegian shelf circulation, Continental Shelf Research 19 (1999) 1809-1831.

[44] L. Anderson, S. Kaltin, Carbon fluxes in the Arctic Ocean - potential impact by climate change, Polar Research 20 (2) (2001) 225-232.

[45] S. Kaltin, L. Anderson, K. Olsson, A. Fransson, M. Cheirici, Uptake of athmospheric carbon dioxide in the Barents Sea, Journal of Marine Systems 38 (2002) $31-45$.

[46] J. Rodhe, On the dynamics of the large-scale circulation of the Skagerrak, Journal of Sea Research 35 (1-3) (1996) 9-21.

[47] E. Svendsen, J. Berntsen, M. Skogen, B. Ådlandsvik, E. Martinsen, Model simulation of the Skagerrak circulation and hydrography during Skagex, Journal of Marine Systems 8 (1996) 219-236.

[48] Den Norske Los 5 - Rørvik-Lødingen og Andenes, Statens Kartverk Sjøkartverket (2001).

[49] R. Sætre, J. Aure, R. Ljøen, Wind effects on the lateral extension of the Norwegian coastal water, Continental Shelf Research 8 (3) (1988) 239-253.

[50] G. Mitchelson-Jacob, S. Sundby, Eddies of Vestfjorden, Norway, Continental Shelf Research 21 (2001) 19011918.

[51] R. Skogseth, P. M. Haugan, M. Jakobsson, Watermass transformation in Storfjorden, Continental Shelf Research 25 (2005) 667-695.

[52] Den Norske Los 1 - Alminnelige opplysninger, Statens Kartverk Sjøkartverket (2004).

[53] B. Gjevik, D. Hareide, Ekstrem vannstandsendring og strøm i Oslofjorden natten mellom 3. og 4. desember 1999, Naturen, Universitetsforlaget 5 (2000) 258263.
[54] B. Gjevik, R. A. Flather, D. Hareide, Sea-level oscillations with 6-h period in the North Sea 29-31 October 2000. An analysis of data from stations in the northern North Sea and along the western coast of Norway, Ocean Dynamics 54 (2004) 477-488.

[55] Norwegian tidal and sea level data, Norwegian Hydrographic Service, Norwegian Mapping Authority, available online: http://vannstand.statkart.no/ (April 2008).

[56] H. Moe, A. Ommundsen, B. Gjevik, A high resolution tidal model for the area around the Lofoten Islands, northern Norway, Continental Shelf Research 22 (3) (2002) 485-504.

[57] B. Gjevik, Moskstraumen. Myter, dikting og virkelighet, in: Årbok 1997, Det Norske Videnskaps-Akademi, Oslo, 2001, pp. 157-169.

[58] T. Wahl, Å. Skøelv, ERS-1 SAR imaging of ocean features in the Vestfjorden area, in: International Geoscience and Remote Sensing Symposium, IGARSS '94. Surface and Atmospheric Remote Sensing: Technologies, Data Analysis and Interpretation, Vol. 4, 1994, pp. 2035-2037.

[59] B. Gjevik, H. Moe, A. Ommundsen, Sources of the Maelstrom, Nature 388 (1997) 837-838.

[60] K. Hjelmervik, A. Ommundsen, B. Gjevik, Modellsimuleringer av tidevannstrømmen i Tjeldsundet og Ramsundet, Mechanics and Applied Mathematics, University of Oslo 1 (2006) 1-61, ISSN 0809-4403.

[61] I. Eliassen, Y. Heggelund, M. Haakstad, A numerical study of the circulation in Saltfjorden, Saltstraumen and Skjerstadfjorden, Continental Shelf Research 21 (2001) 1669-1689.

[62] S. Orre, E. Åkervik, B. Gjevik, Analysis of current and sea level observations from Trondheimsleia, Mechanics and Applied Mathematics, University of Oslo 1 (2004) 1-31, ISSN 0809-4403.

[63] B. Gjevik, D. Hareide, B. K. Lynge, A. Ommundsen, J. H. Skailand, H. B. Urheim, Implementation of high resolution tidal current fields in electronic navigational chart systems, Marine Geodesy 29 (2006) 1-17.

[64] A. Ommundsen, Models of cross shelf transport introduced by the Lofoten Maelstrom, Continental Shelf Research 22 (2002) 93-113.

[65] K. Hjelmervik, A. Ommundsen, B. Gjevik, Implementation of non-linear advection terms in a high resolution tidal model, Mechanics and Applied Mathematics, University of Oslo 1 (2005) 1-34, ISSN 0809-4403.

[66] H. Moe, B. Gjevik, A. Ommundsen, A high resolution tidal model for the coast of Møre and Trøndelag, MidNorway, Norwegian Journal of Geography 57 (2003) 6582.

[67] S. Orre, B. Gjevik, J. H. LaCasce, Characterizing chaotic dispersion in a coastal tidal model, Continental Shelf Research 26 (2006) 1360-1374.

[68] B. Gjevik, E. Nøst, T. Straume, Model simulations of the tides in the Barents Sea, Journal of Geophysical Research 99 (C2) (1994) 3337-3350.

[69] J. Berntsen, Users guide for a modesplit $\sigma$-coordinate numerical ocean model, Tech. Rep. Version 4.1, Department of Mathematics, University of Bergen (September 2004).

[70] $\varnothing$. Thiem, J. Berntsen, Internal pressure errors in sigmacoordinate ocean models due to anisotropy, Ocean Modelling 12 (2006) 140-156. 
[71] Y. Heggelund, F. Vikebø, J. Berntsen, G. Furnes, Hydrostatic and non-hydrostatic studies of gravitational adjustment over a slope, Continental Shelf Research 24 (2004) 2133-2148.

[72] R. Skogseth, A. D. Sandvik, L. Asplin, Wind and tidal forcing on the meso-scale circulation in Storfjorden, Svalbard, Continental Shelf Research 27 (2007) 208227.

[73] I. H. Ellingsen, Internal tides and the spread of river plumes in the Trondheim Fjord, Ph.D. thesis, Norwegian University of Science and Technology (June 2004).

[74] P. J. Martin, Description of the Navy Coastal Ocean Model version 1.0, Tech. Rep. NRL/FR/7322--00-9962, U.S. Naval Research Laboratory (December 2000).

[75] E. Fröberg, Current power resource assessment, Master's thesis, Uppsala University (September 2006).

[76] Potensialstudie av havenergi i Norge, SWECO Grøner, report 154650-2007.1, Enova SF (October 2007).

[77] Den Norske Los 3 - Jærens rev-Stad, Statens Kartverk Sjøkartverket (2006).

[78] Den Norske Los 2A - Svenskegrensen-Langesund, Statens Kartverk Sjøkartverket (2007).

[79] Den Norske Los 2B - Langesund-Jærens rev, Statens Kartverk Sjøkartverket (2005).
[80] Den Norske Los 4 - Stad-Rørvik, Statens Kartverk Sjøkartverket (2003).

[81] Den Norske Los 6 - Lødingen og Andenes-GrenseJakobselv, Statens Kartverk Sjøkartverket (1999).

[82] C. Garrett, P. Cummins, The efficiency of a turbine in a tidal channel, Journal of Fluid Mechanics 588 (2007) 243-251.

[83] C. Garrett, P. Cummins, Limits to tidal current power, Renewable Energy 33 (11) (2008) 2485-2490.

[84] G. Hagerman, R. Bedard, B. Polagye, Guidelines for preliminary estimation of power production by tidal in stream (current) energy conversion devices, EPRI TP-001 NA (August 2005).

[85] A. Westwood, Wave and tidal-project review, Renewable Energy Focus 8 (4) (2007) 30-33.

[86] A. J. Berstad, H. Tronstad, Development and design verification of a floating tidal power unit, in: Proceedings of the 26th International Conference on Offshore Mechanics and Arctic Engineering, OMAE 2007, San Diego, California, USA, 2007, pp. 1-8.

[87] TideTec AS — tidevannskraftverk i Sundstraumen. Bakgrunn for vedtak, Norwegian Water Resources and Energy Directorate (2007). 


\section{A Appendix}

Table 3: The tidal resource estimated for sites along the Norwegian coast based on the available data in parts 5 and 6 of DNL [48,81]. The sites are listed geographically from south to north.

\begin{tabular}{|c|c|c|c|c|c|}
\hline Site from DNL & $\begin{array}{c}\text { MMSS } \\
(\mathrm{m} / \mathrm{s})\end{array}$ & $\begin{array}{c}\text { Note in } \\
\text { DNL }\end{array}$ & $\begin{array}{l}\text { Width } \\
(\mathrm{m})\end{array}$ & $\begin{array}{c}\text { Mean depth } \\
\text { (m) }\end{array}$ & $\begin{array}{c}\text { Resource } \\
(\mathrm{MWh})\end{array}$ \\
\hline Sørsalten & 3.34 & & 40 & 4 & 5 \\
\hline Nærøysundet & 2.31 & & 200 & 40 & 89 \\
\hline Kråkøya & 2.06 & & 400 & 50 & 158 \\
\hline Bakkastraumen & 2.83 & & 60 & 8 & 10 \\
\hline Buholmssundet & 2.06 & strong & 50 & 6 & 2 \\
\hline Toftsundet & 2.06 & strong & 200 & 15 & 24 \\
\hline Visten, Ausa & 2.06 & strong & 400 & 5 & 16 \\
\hline Remmastraumen & 2.06 & strong & 12 & 2.5 & 0.2 \\
\hline Brasøysundet & 2.57 & swift & 70 & 6 & 6 \\
\hline Nesnakroken & 1.03 & moderate & 1600 & 9 & 14 \\
\hline Lamøysundet & 3.09 & very strong & 50 & 7 & 9 \\
\hline By Svenningen & 3.09 & very strong & 50 & 8 & 11 \\
\hline Nordfjorden & 2.06 & strong & 200 & 24 & 38 \\
\hline Sjuløya & 3.09 & very strong & 100 & 10 & 27 \\
\hline Støtt strait & 3.09 & very strong & 150 & 5 & 20 \\
\hline Saltstraumen & 4.37 & & 130 & 25 & 205 \\
\hline Graddstraumen & 3.09 & very strong & 300 & 5 & 40 \\
\hline Husøya - Svinøya & 1.54 & several knots & 50 & 5 & 0.8 \\
\hline By Hopen & 2.06 & strong & 250 & 18 & 36 \\
\hline Area around Røst & 2.06 & strong & 5000 & 40 & 1580 \\
\hline Kjellingsundet & 2.06 & strong & 400 & 5 & 16 \\
\hline Around Værøy & 2.06 & strong & 3000 & 15 & 355 \\
\hline Buholmsflaget & 2.06 & strong & 800 & 45 & 284 \\
\hline Moskenstraumen & 3.09 & & 4000 & 45 & 4798 \\
\hline Kroksundet Beiarfjorden & 1.54 & moderate & 150 & 30 & 15 \\
\hline Engsundet & 3.09 & very strong & 150 & 9 & 36 \\
\hline Nesstraumen & 4.12 & fierce & 370 & 2.6 & 61 \\
\hline Grøtøysundet & 2.06 & strong & 30 & 5 & 1 \\
\hline Akterøya - Aslakøya & 2.06 & strong & 100 & 7 & 6 \\
\hline Sundstraumen Fagernes & 2.06 & strong & 150 & 15 & 18 \\
\hline Kaldvågsstraumen & 3.09 & very strong & 100 & 7 & 19 \\
\hline Dyna - Følfoten & 2.06 & strong & 800 & 32 & 202 \\
\hline Store Bremholmsundet & 2.57 & difficult to pass & 600 & 22 & 202 \\
\hline Litle Bremholmsundet & 1.54 & several knots & 130 & 21 & 9 \\
\hline Gimsøystraumen & 2.31 & & 450 & 12 & 60 \\
\hline Sundklakkstraumen & 4.12 & rapid river & 100 & 2 & 13 \\
\hline Øyhellsundet & 2.06 & strong & 350 & 3 & 8 \\
\hline Kjerringvikstraumen & 2.57 & difficult to pass & 100 & 9 & 14 \\
\hline Sundstraumen & 1.54 & several knots & 100 & 4 & 1 \\
\hline Trangstraumen & 2.06 & & 200 & 12 & 19 \\
\hline Vesterstraumen & 3.09 & & 130 & 3 & 10 \\
\hline Kanstadfjorden & 3.34 & & 100 & 2 & 7 \\
\hline Spannbogstraumen & 1.54 & moderate & 100 & 6.5 & 2 \\
\hline Sandtorgstraumen & 2.06 & & 600 & 10 & 47 \\
\hline Ballstadstraumen & 1.54 & & 350 & 15 & 17 \\
\hline Nordøygrunnen & 2.06 & & 200 & 12 & 19 \\
\hline Steinslandstraumen & 1.03 & & 300 & 11 & 3 \\
\hline Grovfjorden & 2.06 & strong & 50 & 5 & 2 \\
\hline Godfjorden & 1.54 & moderate & 400 & 7 & 9 \\
\hline Mjøsundet & 1.03 & rather strong & 200 & 22 & 4 \\
\hline Salangverket & 3.09 & very strong & 400 & 50 & 533 \\
\hline Risøyrennan & 1.54 & & 100 & 6 & 2 \\
\hline Nappstraumen & 1.03 & & 1000 & 17 & 17 \\
\hline Hamsundpollen & 1.54 & several knots & 50 & 5 & 0.8 \\
\hline N Nappstraumen & 2.31 & & 730 & 15 & 122 \\
\hline
\end{tabular}


Table 3 - continued from previous page

\begin{tabular}{|c|c|c|c|c|c|}
\hline Site from DNL & $\begin{array}{c}\text { MMSS } \\
(\mathrm{m} / \mathrm{s})\end{array}$ & $\begin{array}{c}\text { Note in } \\
\text { DNL }\end{array}$ & $\begin{array}{l}\text { Width } \\
(\mathrm{m})\end{array}$ & $\begin{array}{l}\text { Mean depth } \\
(\mathrm{m})\end{array}$ & $\begin{array}{c}\text { Resource } \\
(\mathrm{MWh})\end{array}$ \\
\hline North of Napp - E Hundholmen & 1.29 & & 1000 & 22 & 43 \\
\hline Sundvollsundet & 1.03 & rather strong & 150 & 10 & 1 \\
\hline Meistervik & 2.06 & strong & 100 & 6 & 5 \\
\hline Rystraumen & 3.09 & & 480 & 30 & 384 \\
\hline Hekkingesundet & 2.06 & strong & 50 & 5 & 2 \\
\hline Straumen, Sørfjorden & 1.54 & swift & 400 & 10 & 13 \\
\hline Tromsøysundet & 1.54 & & 200 & 7.5 & 5 \\
\hline Angstaursundet & 1.54 & moderate & 50 & 40 & 7 \\
\hline Storstraumen & 4.12 & rapid river & 100 & 5 & 32 \\
\hline Sørsundet & 2.06 & strong & 200 & 3 & 5 \\
\hline Buholmen & 2.06 & strong & 100 & 5 & 4 \\
\hline Kvalsundet Troms & 3.09 & & 770 & 15 & 308 \\
\hline Kjøfjorden & 1.03 & rather strong & 200 & 15 & 3 \\
\hline Store Vågsøysundet & 2.06 & strong & 1000 & 40 & 316 \\
\hline Litle vågs øysundet & 2.06 & strong & 400 & 10 & 32 \\
\hline Storstraumen & 2.57 & hard to pass & 200 & 7 & 21 \\
\hline Lyngøya & 2.06 & strong & 300 & 12 & 28 \\
\hline Maursundet & 1.03 & & 800 & 32 & 25 \\
\hline Gjøss øysundet & 2.06 & strong & 250 & 5 & 10 \\
\hline Vesterbotn & 3.09 & very strong & 200 & 3 & 16 \\
\hline Burøysund & 1.03 & & 100 & 5 & 0.5 \\
\hline Brynilen, Svartskjer & 3.09 & very strong & 4000 & 26 & 2772 \\
\hline Steikarviksundet & 1.03 & rather strong & 300 & 6 & 2 \\
\hline Kjesundet & 1.03 & rather strong & 400 & 30 & 12 \\
\hline Marholmen - Bergsfjorden & 3.09 & very strong & 400 & 2 & 21 \\
\hline Skagøysundet & 1.70 & & 700 & 30 & 93 \\
\hline Kågsundet & 1.03 & & 500 & 100 & 49 \\
\hline Gåsan & 1.54 & moderate & 500 & 5 & 8 \\
\hline Kvalsundet & 1.80 & & 600 & 45 & 142 \\
\hline Austertana & 3.09 & very strong & 70 & 4 & 7 \\
\hline Straumen, Hammerfest & 1.29 & & 800 & 75 & 116 \\
\hline Darupskjæret & 1.54 & & 200 & 16 & 11 \\
\hline Vargsundet & 1.03 & rather strong & 140 & 15 & 2 \\
\hline Inner Andamsfjorden & 1.03 & rather strong & 300 & 12 & 4 \\
\hline Kartøysundet & 3.09 & very strong & 1400 & 40 & 1493 \\
\hline Kamøysundet - Lilla Kamøya & 4.12 & rapid river & 50 & 6 & 19 \\
\hline Inlet to Straumsfjorden & 3.60 & & 220 & 3 & 25 \\
\hline Reinøyspira & 1.03 & rather strong & 200 & 27 & 5 \\
\hline Around Latøyan & 3.09 & very strong & 400 & 30 & 320 \\
\hline Magerøysundet & 2.06 & & 1100 & 40 & 348 \\
\hline Måsøysundet & 1.54 & & 2500 & 40 & 330 \\
\hline Havøysundet & 1.54 & several knots & 50 & 6 & 1 \\
\hline Bårdsetsundet & 1.03 & rather strong & 500 & 44 & 22 \\
\hline Lauksundet & 1.03 & & 400 & 12 & 5 \\
\hline Grøtøysundet Troms & 2.06 & strong & 1100 & 35 & 304 \\
\hline Vesterbotn - Brennelvfjorden & 3.09 & very strong & 100 & 4 & 11 \\
\hline Trollsundet & 3.09 & very strong & 1000 & 19 & 506 \\
\hline Tørrbåan & 1.54 & & 800 & 8 & 21 \\
\hline Svartviknæringen & 1.54 & moderate & 200 & 30 & 20 \\
\hline
\end{tabular}

